\title{
Analysis of Quality Models Applied in Non-Formal Education: Non-Governmental Organizations and Nonprofit Organizations
}

\author{
Alfonso Conde Lacárcel, Juan Antonio López Núñez, María Angustias Hinojo Lucena \\ Faculty of Sciences Education, University of Granada, Granada, Spain \\ Email: alfconl8@ugr.es, juanlope@ugr.es
}

Received 24 January 2015; accepted 8 June 2015; published 11 June 2015

Copyright (C) 2015 by authors and Scientific Research Publishing Inc.

This work is licensed under the Creative Commons Attribution International License (CC BY). http://creativecommons.org/licenses/by/4.0/

c) (7) Open Access

\section{Abstract}

The article is part of the research project entitled "The Implementation of Educational Quality Standards for Non-Formal Education: Non-governmental organizations (NGOs), Partnerships dedicated to working with socially excluded groups". The project was supported by the Research Plan of the University of Granada. It's an initial study on the degree of implantation of quality models in Non-governmental organizations and Non Profit Organizations (NGOs and NPOs), and methodology of work developed in non-formal educational activities in the city of Granada (Andalusia, Spain). We have pursued a mixed methodology quasi-experimental descriptive for a random sample of 9 class organizations of the third sector of social action, using two questionnaires specifically created from already validated and a set of semi-structured interviews to complete the information. The obtained results offer us a poor implementation of the EFQM model of European Foundation for Quality Management in this kind of micro organizations and the need for optimization of internal work process face of accountability, improvement of services and the achievement of its objectives.

\section{Keywords}

Educational Quality, Nonformal Education, ONGS, Social Exclusion

\section{Introduction: Welfare State, Non-Formal Education and Quality Models}

Since early in the nineteenth century, the idea of rule of law based on equality has occurred before the law for all citizens, through its evolution into the state's obligation to respond to different social purposes (social state) and arriving to our days at welfare state; the latter has suffered since its inception in Europe after the Second World 
War many advances, brakes and setbacks that continue to result in major legislative changes and performing about the different social policies [1] [2].

This conception of that derives a set of state policies partly transferred private market and non-profit includes a wide range of basic services among the education and the right to training. [3] warns us about privatization and loss of fundamental unction in favour of the competitiveness of the labor market and the strengthening of traditional conceptions of various pressure groups.

Public protection systems today are being modified by factors like globalization, modification of international law, competence of international markets and the economic crisis [4]. Meanwhile, the associative capacities of individuals are strengthened by the civil society, while the ties seem weakened of the State in favor of financial recovery and sustainability of the system.

Within this scope, the Third Sector plays a fundamental role in non-formal education and is defined by the Non-governmental organization Platform Social Action as:

El ámbito formado por entidades privadas de carácter voluntario y sin ánimo de lucro que, surgidas de la libre iniciativa ciudadana, funcionan de manera autónoma y solidaria tratando, por medio de acciones de interés general, de impulsar el reconocimiento y el ejercicio de los derechos sociales, de lograr la cohesión y la inclusión social en todas sus dimensiones y de evitar que determinados colectivos sociales queden excluidos de unos niveles suficientes de bienestar [5].

“The field was made up of private entities and of a voluntary nature nonprofit that arose from the free citizens' initiative, work autonomously and severally trying, through actions of general interest, to promote the recognition and exercise of social rights of achieving cohesion and social inclusion in all their dimensions and prevent certain social groups being excluded adequate levels of well-being.” (Translation done by the authors)

Therefore, we have proposed an exploratory study in small organizations that develop educational and/or activities formative, their organizational structures and methodologies outside the regulated systems, complementing them and supporting the development of aspects such as emotional education, intercultural coexistence, social responsibility and who work with sectors of the population under risk of exclusion.

According to UNESCO, non-formal education (NFE) is defined as: "toda actividad organizada y duradera que no se sitúa exactamente en el marco de los sistemas educativos formales integrados por las escuelas primarias, los centros de enseñanza secundaria, las universidades y otras instituciones educativas formalmente establecidas" [6].

"All organized and enduring activity is not placed accurately in the framework of formal educational systems comprised of primary schools, secondary schools, universities and other educational institutions established formally." (Translation done by the authors).

We believe that this is an area that has not been taken into account in all its importance for the development of individuals and formation of a critical and engaged citizenship, despite having been the subject of many studies [7]-[11].

Education throughout life appears as one of the focuses of attention today when we refer to non-formal education. According to the report of World Bank [12], the number of countries prepared projects on non-formal basic education increased, particularly in developing countries and for a very specific population (children out of school, elementary, youth, groups under risk of exclusion and adult education). We can find a wide range of action in which the Non-governmental organizations and Non Profit Organizations (NGOs and NPOs) have a fundamental role. For example, non-formal education can be seen as:

1) A wide range of discrete and disparate activities by different agencies for adults, usually small-scale and localized.

2) Institutionalization: large-scale/national systems.

3) Adult literacy.

4) Alternative primary education for out-of-school children.

5) Action within formal education.

6) Feeder schools within the educational system [10].

Today, we see another example in the Office of Non-Formal Education of UNESCO Dhaka, India [13] which states as areas of non-formal education programs:

1) Early childhood care and education (ECCE).

2) Alternative opportunities through non-formal channel for basic education of children not able to participate in formal primary schools for various reasons. 
3) Second-chance opportunities for non-formal basic education of adolescents and adults of 16 - 24 and 25+ age group, who never enrolled in or dropped-out from of primary schools.

4) A full menu of continuing education programs for lifelong learning opportunities.

5) Training through non-formal channels in vocational, entrepreneurship, and employment related skills together with support for access to micro-credit or micro-finance.

The scope of NFE according to Unesco has as its priorities to street children, working children, youth and adults from disadvantaged groups, having disabilities, ethnic minorities, and issues relating to basic literacy, local, national problems and goals global, skills related to daily life, health programs, etc.

Own regulations by the European Community were intended as a complement to formal educational systems especially directed to young people, the labor market, promoting social inclusion and citizen participation; all this, following the Lisbon and the European area of lifelong learning since 2002.

In Spain, NFE keeps close relationships with social needs of the various partners and collaborators, the education system and quality oriented primarily about the socio-cultural entertainment and recreational services, and adult education specialized in accordance with studies conducted by different authors [14].

There are numerous investigations on the impact of the processes of non-formal and informal education in the development of subjects, their relationship with the school and social change. We find, for example, works like those by [15] on the significance of non-formal education institutions of lifelong learning, not so much when we evaluate and check the real effectively and how many they are implementing or beginning to implement the European Foundation for Quality Management model (EFQM) and other systems of quality management.

What extent do these small organizations adapt to the new requirements of society? Is the application of a model of quality management, and more specifically the EFQM Model, a real improvement in work processes and outcome concerning the users? Is it possible to implement this model in NGOs and NPOs at local level or limited in infrastructure?

According to the [16] "The Declaration of Commitment for Quality in the Third Sector was presented in Madrid in 2006 in Congress on Quality, Third Sector and Social Policy. To date, 73 organizations have signed.”

Different professionals and researchers coincide in the view that the efficient application of the models created specifically for this kind of organization generates more efficient in achieving the objectives to working with the different groups to which they have access [17] [18].

[19] Gives us an initial idea:

"The role of civil society is increasing dramatically in different areas of interest to the public $[\cdots]$ collaborative initiatives $[\cdots]$, although it is true that in many cases these initiatives are carried out in a manner discontinuous and somewhat precarious by the shortage of human and material resources.”.

The progressive implantation of these quality models to NGOs and NPOs is an indisputable fact in singular organizations in second and third level (federations and confederations).

Some authors argue that in the organizations what we talked (small or very small) means assuming the enormous cost and effort to implement a system based on organizational processes such as the initial self-assessment of the entity, the generation of action plans, measuring impact of their actions, compliance with the requirements of (public and private) funding, recipients and families, etc., due to problems such as the lack of involvement of staff, the rush to implement it and the lack of resources [20].

In the report by [21], under the 1st Encounter of development NGOs, reference was made regarding the EFQM model some initial substantial costs for small organizations that in many cases cannot afford (approx. $€$ $5000)$.

So, on the website of [22], we can find an excerpt of the interview of Paulino Azua, chairman of the executive committee for the quality of NGOs: "In the world of NGOs it has permeated slowly, although there is still much to be done, and there is the need to improve their own processes. Not enough to do well, but do it right."

The EFQM model aims to, with the help of a management system based on the adaptation, meet the needs of each company oriented towards excellence work, allowing flexibility with other models, ethical codes and standards and promoting the participation of people, among other things. Authors such as [23] [24] focused their glances at this issue.

The main objective involves identifying of the strengths of the organization and defining the areas for improvement. For these reasons, it is essential to clearly define whether these quality models improve the service of social agents that complement the work of the State, leverage resources, and offer educational activities that 
meet the goals set by each.

This research has taken as primary sources and existing research studies to avoid worked aspects and offer a new perspective. Among others we can quote [25] or Gutiérrez Nieto:

"This is an exploratory access $[\cdots]$ that in terms of meanings from the perspective of the participants, $[\cdots]$ where the context is reflected in a report in sufficient detail is considered essential so that the reader outreaches to know what is to be there." [26].

A review has also been conducted of all the literature on quality management systems: from the State Council of Social Action NGOs, through the articles and reflections by [27] [28] and in journals specializing in the third sector as the "2009 Guide Transparency and Good Practice for NGOs" or guidelines for implementing the EFQM Model [29] for social action organizations; or the "Guidelines for the development of a memory EFQM schools".

The facilitator agents incorporated in the model report how far the Directorate is implicated in quality?, [] how objectives are defined and set priorities?, how to classify and assess the capabilities of the members of the organization?, how learning is encouraged to achieve quality improvement?, emphasizes efficiency?, $[\cdots]$ how the processes are defined?, or is it regularly reviewed? [30].

The objectives and novelty of the study submitted have passed to carry out an initial discovery of this quality systems implementation in small and very small organizations, and identify the working methodology used for the teaching of values according with NGOs and NPOs. In this way, we wanted to provide a real insight and possible improvement lines of the work of these actors in different contexts of socio community intervention groups at risk of exclusion.

\section{Method}

To try to answer the main objective of proposed research on the degree of implementation of model quality and its impact on non-formal education in small organizations, we have established a number of specific objectives in order to analyze and evaluate different aspects, namely: identify the methodology for teaching; evaluate the effectiveness of this educational work through the various questionnaires and interviews and then verify or not improve their organizational and logistical systems.

The design used, has followed a methodology of quasi-experimental research applied descriptive section, with respect to the naturalness of the groups to observe and have desirable levels of validity and reliability as well as its low cost; trying to see if statistically significant relationships between implementation of management system quality and outcomes of the educational activities occur.

Two questionnaires were designed: the "Questionnaire to assess the level of implementation of quality standards for non-formal education” for educators and professionals (with 178 elements and a Cronbach's alpha reliability of 0.95); and "Customer satisfaction questionnaire—user" (with 26 elements and a Cronbach's alpha of 0.88) from other already validated for their proven reliability and use this area [31]-[36] Semi-systematized open response interviews were designed to obtain qualitative information, which was contrasted with objective data previously collected.

Also we highlight the comprehensive analysis of a trial of four experts composed of professionals in the field of non-formal education and Higher Education College about the content of questionnaires and interviews in order respond to our research needs.

Quantitative instruments respond to a Likert scale with an answer graduation 1-4 along with 2 elements required for checking the applicability of the system of quality management and educational work done and establish significant differences between them in our research: na (not applicable) and ns (do not know, no answer). The areas investigated analyze the following factors:

- Functioning of the organization:

- Ideas about quality.

- Action Protocols.

- Priorities for action.

- AssessmentSystems.

- Degree of satisfaction.

- Communication. 
- Directorate.

- Professional.

- Volunteers.

- Advantages and disadvantages of the implementation of quality systems.

- Educational work developed:

- Planning.

- Methodology.

- Activities.

- Evaluation.

- Professional.

- Potential impeders' elements of learning.

Selected sample, as seen in Table 1, forms part of the 149 NGOs and NPOs first cultural level and that cater to diverse groups located in the city of Granada, developing educational and training work a total of 168 making up the total population of these organizations. Focused initially on 3 beneficent associations-Cultural and care for children, youth and women at risk of social exclusion with a minimum experience in this community partner area between 3 - 5 years; the development of under research had to be expanded to 9 NGO and ONL, in order to obtain reliable data minimally.

For collecting data, we visited NGOs and NPOs dedicated to working with at-risk groups in order to establish favorable information channels and involvement by the potential benefits that this kind of research to society and community development.

We made direct contacts with professionals and volunteers in their work contexts avoiding hinder their work, providing both them and users who attended these centers received questionnaires.

Interviews were transcribed by hand initially and subsequently recorded on audio, and have allowed us to develop a vision of non-formal education in particular NGOs and NPOs enough. The different data obtained were analyzed using SPSS v.17.0 and techniques based on biographical narrative discourse.

\section{Results}

Of the 9 organizations investigated, one applied the EFQM Model and 2 others were in various implementation processes. The rest did not apply any quality system.

Majority are private institutions with a strong motivation in solidary values. The $66.7 \%$ have a staff of between 11 - 15 people, and $33 \%$ of 2 - 5; the budgets ranging from less than $5000 €$ for those who develop up to 3 programs of various kinds, to those which exceed $€ 50,000$ and reach a larger group of people at risk of social exclusion.

From our expertise in the field as coordinators of some projects, we can affirm that this is due to instability in the annual budgets. Most of the funds come from annual grants or donations, making it difficult to maintain a stable staff and broad enough to work effectively, at the same time determines the number of projects that can be made along the way.

For all this the role of the volunteer is essential, being the most played professional profile with $38.9 \%$. The $66.7 \%$ are between $50-60$ volunteers intermittently depending on the activity, or more stable over the years working in different educational activities; serving an average of 100 users per year.

The rest of profiles are divided between $27.8 \%$ educators, psychologists the $11.1 \%$, the $5.6 \%$ social workers and managers, and $11.1 \%$ of various profiles. Another aspect is the predominance of the female gender with $77.8 \%$ on $22.2 \%$ men.

Among the obtained significant results, we can say that the planning and development of graduate and innovative educational activities is the "cornerstone" with which we work every day, along with other aspects such as the clear definition of the steps or collaboration with families (see Figure 1), in addition to communication internally and with donors.

An example can be the answer given to the question: "Tell me about the planning of educational activities that develop along the course" made in interviews:

"You try to look for what you like, workshop, course, If not arrive in the early going, try to customize. And look at the educational activities which are lacking $[\cdots]$ then contracted educator to organize everything. $[\cdots]$ Depending on the needs you are planning." (J. educator of a social intervention project with children and young people in deprived neighborhood).

The personal aspects related to human resources capacities of NGOs, NPOs, such as the ability of empathy or 
Table 1. Population and study sample (2010/2011).

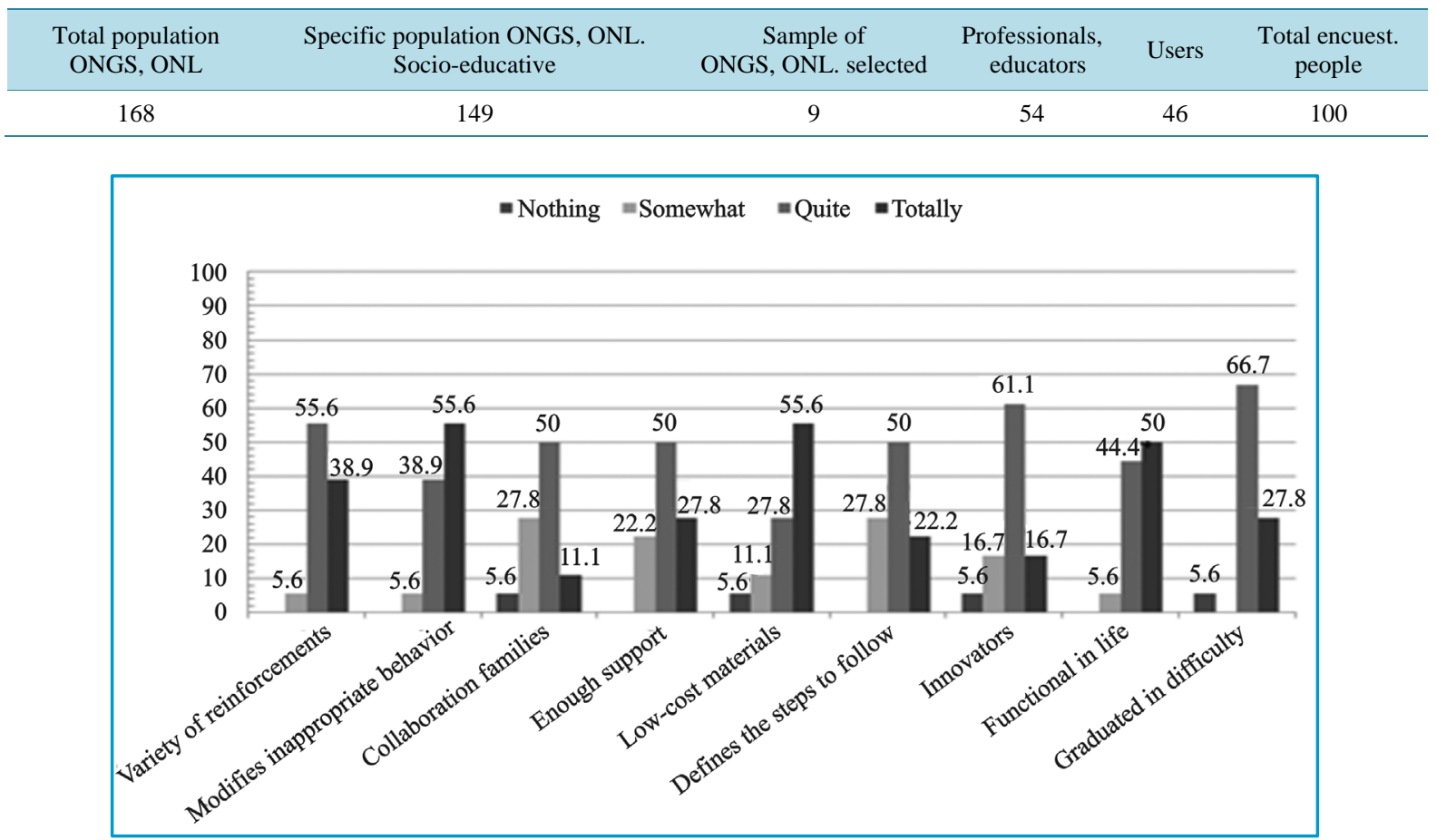

Figure 1. Methodological issues related to planning educational activities. Source: own.

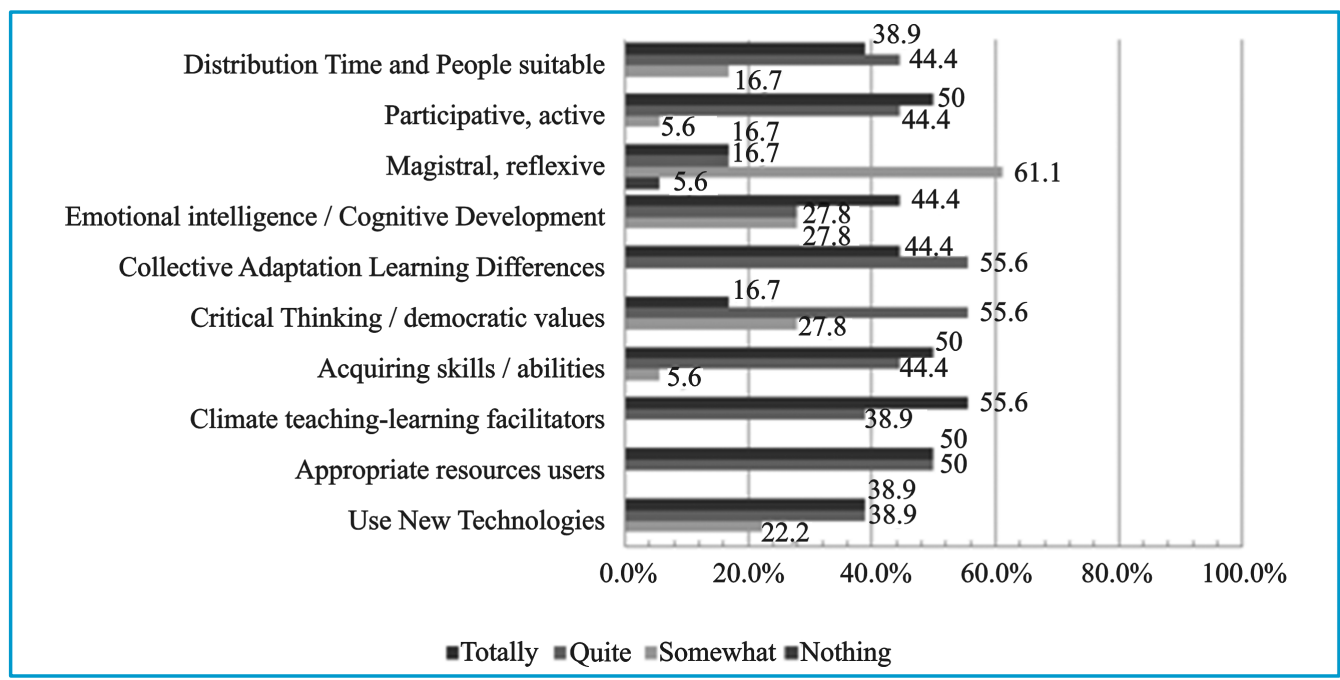

Figure 2. Methodological issues related to the development of educational activities for NGOs and NPOs. Source: own.

possess adequate interpersonal skills, together with a methodology based on emotional intelligence and cognitive development, modification of misconduct, the adaptation to learning difficulties and functionality to everyday life are other pillars on which their work is based, as we can see in Figure 2.

Then are highlighted in the assessment of the respondents, the following issues that needs to be improved, related to quality:

- The degree of short-term deployment of these systems.

- The time for review and evaluation of the mission.

- The compliance with external requirements. 
- The quality control of materials and cost.

- The equipment.

- The degree of customer satisfaction.

Quality is seen as a pending matter; ensuring enough support for educational activities and practical application of learning by users, is a daily concern of all members of the organization.

More specifically in Figure 3, a summary of the most valued items related to quality, we can appreciate the importance of implementing a quality system, the measure of satisfaction and valuation for the communication with the different stakeholders (professionals, users, donors, different organizations) are the most valued items (remember that the Likert scale has a graduation degree 1 - 4 according to the different statements, with 4 being the highest agreement).

It is followed lesser extent, aspects such as the importance of quality for the Third Sector; developing priority action lines or a temporary adequate planning at the time of develop quality-related, among other activities.

Noteworthy are the low percentages referring to the existence of action defined protocols and tools for measuring the quality or; the involvement of volunteers and partners in these organizations.

Among the users, $51.6 \%$ are male and $48.4 \%$ female. The study encountered academic education is in secondary education (35.5\%), baccalaureate (29\%) and primary or no education (15\% respectively). By nationality, mainly come of the country itself at 51.6\% (Spain); followed by 19.4\% from Morocco, and to a lesser measure people coming from Colombia (9.7\%) and Bolivia (9.7\%), as well as Ecuador and Pakistan.

Mainly engaged in manual workshops (62.4\%); recreational activities (20.4\%) and educational support (17.2\%).

As we can see in Figure 4, most appreciated is the degree of general satisfaction with the NGO-NPO. The information received about activities and projects in which they can participate; perception of the smooth functioning of the organization; confidence in the NGO; the resolution of conflicts through dialogue; and the quality and appropriateness of good times for the activities, are other positive points mentioned.

Concern about the family environment of the people who attend these NGOs and NPOs, as well as specific age stretches of whom they are addressed throughout the work, harmony, the impact on the immediate environment, and information about other possible services they could provide them, are other noteworthy aspects.

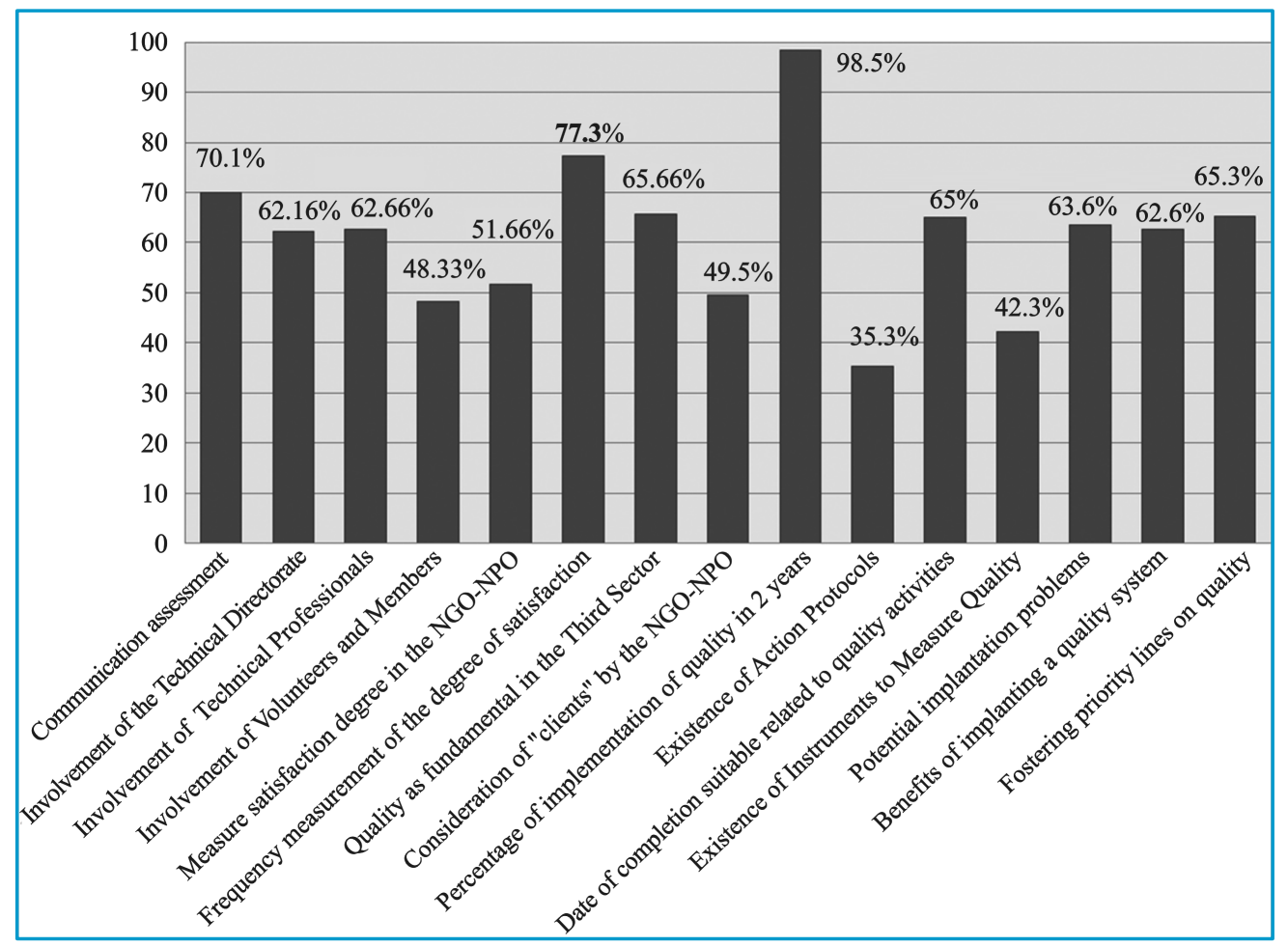

Figure 3. Percentage of valuation of the different items related to quality. Source: own. 


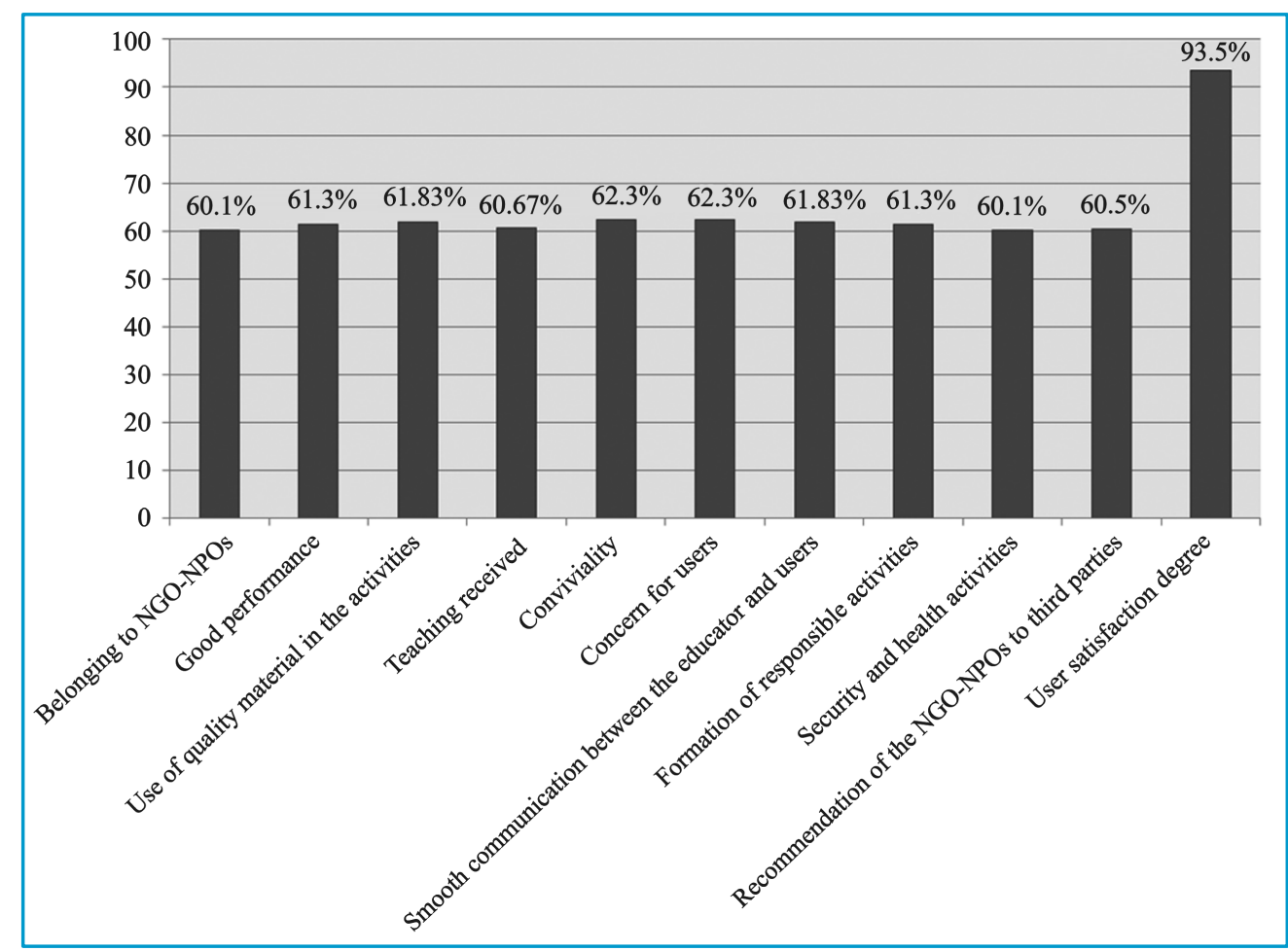

Figure 4. Most valued aspects by users. Source: own.

Moreover, the lowest percentages of accordance we find about the organization of activities with other NGOs-NPOs the immediate environment (47.5\%); followed by the execution time of activities and collaboration with official entities (50\% each) and information on the various projects and activities in which they can participate (51\%); as we can see in Figure 5.

\section{Discussion}

It has been noted that the status of implementation of systems quality management in NGOs and small or very small nonprofits that develop educational activities in non-formal contexts, just is in an early stage. Only 3 of 9 NGOs researched were interested in improving their organizational and logistical systems, the rest regarded it somewhat bureaucratic, a waste of effort and time that could be used in the proposed activities with different groups at risk of exclusion with which work.

At the same time, the different elements of the EFQM model and its actual function are unknown, and those which do seemingly are implemented by the need to adapt to the rules being generated in order to get any grants for which are nurtured their projects, rather than by desire to improve their management and operation.

Most of them do not consider people who use its services as "clients" and only intended to solve problems that require empathize with the person and give them the best solution in the shortest time possible with the resources that are available or prevented by educational activities conducted.

A notable aspect in the light of the interviews was based on the concern of losing their identity and values towards achieving the objectives.

NGOs, NPOs observed hire staff based on annual funds to that account. So easy to find job saturation in people highly committed to these groups.

Moreover, the effectiveness of the educational work of considering the impact and degree of satisfaction of users though improved is obvious and essential. Evaluation of operational objectives is the fundamental tool used as a first filter reflected in the schedules and course start projects, which are reviewed at least once per quarter.

An example might be the answer given by T. psychologist contracted in one of the NGOs: "What if you get what you want? If it is true that I am seeing changes, but are very small. So are achieved if for example you have 


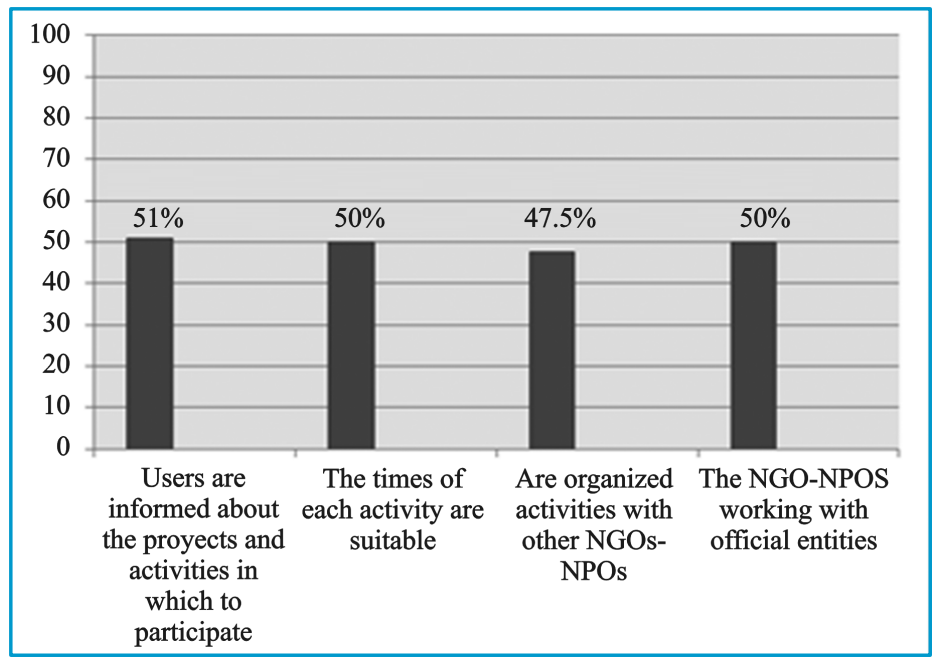

Figure 5. Items less valued by users. Source: own.

10 goals, because you get $1-2$. Something you get.”

The work methodology used, tailored to each NGO is primarily active, recreational and very participative. It seeks to catch the users' attention, according to their interests, needs ... and combining the adjustment to different levels of learning with different types of reinforcements and respect for the proposed rules. All these fundamental tools.

What is important in itself is knowing them get different content in the best possible way to the person in front of you; adapting to their culture, thought, trouble...

In the data obtained we can appreciate the need for learning activities promote life skills, while also intervening on the surrounding environment. Previously on other research as Martin Moreno (2004) we are warned that we are facing an attempt to get a proper overview of this reality.

With the above, we believe to have obtained a first fairly accurate picture of the reality of these organizations, although further investigations needs to be developed in this line to help reassert or refute the initial problem that we started. That is supported studies such as that conducted by Garcia Alonso (2007) for the Spanish reality around the use of quality systems.

The main constraints found in this research have focused on the difficulty of gather the information due to the need not to interfere in the activities of these organizations and the low importance given to quality systems by professionals, volunteers and users.

We recommend prepare questionnaires online, demanded by some of the organizations at the same time facilitate both the collection of information, such interfere with their educational work, since it can be performed at any time in accordance with an agreed delivery date.

Equally as new research, it is proposed to extend the study to other types of rules, models and quality systems used by its relevance.

\section{Conclusions}

In conclusion, we may venture to anticipate a strong impact in terms of professional advancement of these kinds of organizations through innovation, transformation and upgrading their problem solving processes, and dialogue with the various government agencies, NGOs, researchers, etc.

Likewise we expect the resulting data that improve educational and/or training processes in the field of nonformal education; initiate processes of coordination with organizations specializing in quality models and the implementation and establishment of a collaborative network between different micro NGOs and NPOs complementing the different interventions undertaken.

\section{References}

[1] Muñoz, S., Delgado, J.L., and González, L. (Dir.) (2000) Las estructuras del bienestar en Europa. Editorial Civitas, España. 
[2] Urteaga, E. (2012) Los estados de bienestar ante la globalización. Portularia: Revista De Trabajo Social, 12, $213-219$. http://dx.doi.org/10.5218/prts.2012.0023

[3] Carrera, M.P. and Luque, E. (2012) Competencias educativas: Neoliberalismo y educación. El Viejo Topo, 293 , 58-62.

[4] Alemán, J.J. (2013) De la sociedad del riesgo al desmantelamiento del estado de bienestar. Dilemata, 11, 139-147.

[5] Plataforma de Ong de Acción Social (2012) Diagnóstico del Tercer Sector de Acción Social. Plataforma de ONG de Acción Social, Madrid.

[6] U.N.E.S.C.O. (2006) Educación No Formal. August 12, 2010. http://www.unesco.org/bpi/pdf/memobpi55_NFE_es.pdf

[7] Gutiérrez, C. (2003) Evaluación de programas de educación no formal. Una propuesta etnográfica naturalista. Ágora digital, n.4. August 12, 2010. http://rabida.uhu.es/dspace/bitstream/handle/10272/3503/b1576168x.pdf?sequence1

[8] Martín-Moreno, Q. (2004) Centros educativos y ONGS: Análisis de los modelos emergentes de interrelación. UNED, Madrid.

[9] Rogers, A. (2005) Non-Formal Education: Flexible Schooling or Participatory Education? Springers Science Business Media Inc., USA.

[10] Gallego, J.I. and Barragán, B. (2008) Pedagogía crítica y movimientos sociales: Apuntes para el debate de una educación no formal crítica. Uni-pluri/versidad, 8, 71-78.

[11] World Bank (2001) Report of Distance Learning Seminar: Use of Outsourcing in the Implementation of Literacy and Non-Formal Basic Education Programs. World Bank Paper, Washington.

[12] NFEMIS (2010) What Is the Scope of NFE? http://www.nfemis.bnfe.gov.bd/index.php?option=com_content\&view=article\&id=47:what-is-nfe\&catid=35:nfemis-co nceptaul-manual\&Itemid=142\&lang=en

[13] UNESCO (2013) http://www.unesco.org/bpi/pdf/memobpi55_NFE_es.pdf

[14] Luque, P.A. (1998) Ámbitos de acción en educación social y animación sociocultural. In: Pérez, G., Ed., Contexto Cultural y Socioeducativo de la Educación Social, Universidad de Sevilla, Sevilla.

[15] López, J.A., Trujillo, J.M. and Lorenzo, M.E. (2009) La importancia de las instituciones de educación no formal en el aprendizaje a lo largo de toda la vida. El caso de las universidades populares españolas: Un estudio a nivel nacional. Revista de Ciencias de la Educación: Órgano del Instituto Calasanz de Ciencias de la Educación, 217, 23-39.

[16] Plataforma de ONG de Acción Social (2010) Declaración de compromiso por la calidad en el tercer sector de acción social (Folleto). http://www.plataformaong.org/declaracion-de-compromiso.php

[17] García, J.V. (2007) Instrumentos para la gestión de la calidad en las ONG: Perspectiva internacional. Fundación Luis Vives: Madrid.

[18] Giraldo, E. (2008) Sistemas de gestión de calidad en organizaciones no gubernamentales para el desarrollo (ONGD) [Versión Electrónica]. Tesis para optar al título de Doctora en Organización, Administración de empresas y estadística. Depto. de Ingeniería de organización, administración de empresas y estadística. Universidad Carlos III. Madrid. España. Tesis doctoral publicada en e-archivo de la Universidad Carlos III. http://hdl.handle.net/10016/5097

[19] Cantón, I. and Álvarez, M. (2001) La implantación de la calidad en los centros educativos: Una perspectiva aplicada y reflexiva. CCS, Madrid.

[20] Moreno, J.L. (2007) Guía para la aplicación del Modelo EFQM de Excelencia en entidades de acción social. Cuadernos de Gestió, Vol. 2, Fundación Luis Vives, Madrid.

[21] CONGDE (2007) La calidad en las ONGD. Situación actual y retos. CONGDE, Madrid. https://www.google.es/url?sa=t\&rct=j\&q=\&esrc=s\&source=web\&cd=1\&ved=0CCEQFjAA\&url=http\%3A\%2F\%2Fw ww.congde.org\%2Fcontenidos\%2Fdescargar\%2Fattachedfiles\%2F964\%2Foriginal\%3F1363750391\&ei=uzVsVcmOF cK8UeuVg8AP\&usg=AFQjCNH_kcI4H1GPWYCwooxQoG_bNjWoiw\&sig2=BHYUcEbH4bOk4sKvFUvuDA\&bv m=bv.94455598,d.d24

[22] Unión de Asociaciones y Entidades de Atención al Drogodependiente (UNAD) (2008) http://calidad.unad.org/novedades

[23] Avlonas, C.G., Cliffe, R., Dibley, D., Jevons, J., Ludwing, W., et al. (2003) Conceptos Fundamentales de la Excelencia (Versión Electrónica). EFQM, Bruselas. http://issuu.com/dxesau/docs/efqm - conceptos fundamentales

[24] Vall, N. (2007) Instrumentos para la gestión de la calidad en lasONG: Perspectiva internacional. Fundación Luis Vives, Madrid.

[25] Castillo, S. and Cabrerizo, J. (2004) Evaluación de programas de intervención socioeducativa: Agentes y ámbitos. Madrid: Pearson Educación.

[26] Gutiérrez, C. (2003) Evaluación de programas de educación no formal. Una propuesta etnográfica naturalista. Ágora digital, No. 4, 6. http://rabida.uhu.es/dspace/bitstream/handle/10272/3503/b1576168x.pdf?sequence1 
[27] Fernández, M.J. and González, A. (1997) Desarrollo y situación actual de los estudios de eficacia escolar (Versión Electrónica) Relieve, 3, 1. http://www.uv.es/RELIEVE/v3n1/RELIEVEv3n1_3.htm

[28] Escudero, J.M. (1999) Calidad de la educación: Entre la seducción y las sospechas (Versión Electrónica). Heuresis, 2, 5. http://www2.uca.es/HEURESIS/heuresis99/v2n5.htm

[29] Sanz, R. (2007) Orientación Psicopedagógica y Calidad Educativa. Edit. Pirámide: Madrid.

[30] Carot, J.M., Girones, M. and Jabaloyes, J. (2007) Guía para la elaboración de una memoria EFQM en centros educativos [Versión Electrónica]. Conselleria d’Educació, Valencia. http://www.edu.gva.es/eva/docs/novedades/es/GUIA_EFQM.pdf

[31] Buendía, L. (1993) Análisis de la Investigación Educativa. Servicio de Publicaciones, Granada.

[32] Ellard, J.H. and Rogers, T.B. (1993) Teaching Questionnaire Construction Effectively: The Ten Commandments of Question Writing. Contemporary Social Psychology, 17, 17-20.

[33] Dapía, M.D. (2002) Evaluación de programas de educación no formal: Hacia una propuesta integradora [Versión Electrónica]. Revista de Ciencias de la Educación, 191, 375-392. http://bddoc.csic.es:8080/ver/ISOC/revi/0102.html

[34] Alaminos, A. and Castejón, J.L. (2006) Elaboración, análisis e interpretación de encuestas, cuestionarios y escalas de opinión. Marfil, Alcoy.

[35] Gutiérrez, A.I. and Peña, M.J. (2008) Cuestionarios de respuestas múltiples. Estudio de Técnicas Documentales, Madrid.

[36] Conde, A. and López Núñez, J.A. (2013) Diseño de un cuestionario para la aplicación de los estándares de calidad educativa a la educación no formal. Revista de Ciencias de la Educación: Órgano del Instituto Calasanz de Ciencias de la Educación, 235, 263-282. 